\title{
Effect of Compost-amended Backfill and Paved Surface on Leaf Parameters and Physiology of Norway Maple (Acer platanoides L.)
}

\author{
Francesco Ferrini and Manuela Baietto
}

\begin{abstract}
We compared the effects of compost-amended backfill and of the size of the exposed surface area on Norway maple (Acer platanoides L.) trees planted in a high-quality backfill on a brownfield area previously occupied by a truck factory. After 3 years, trees with larger and mulched planting areas had higher leaf gas exchange, leaf chlorophyll, and mineral content than those grown under pavement. The effects of the different quantities of compost in the backfill were more difficult to assess within the framework of this study. Although these effects may become significant in the long term, it is difficult to prescribe compost addition as a useful technique to improve plant growth and physiology when the native soil has been completely replaced by good topsoil.
\end{abstract}

Key Words. Chlorophyll; compost; leaf mineral content; mulching; photosynthesis; tree establishment.

Reclamation of postindustrial landscape in Italy is important not only for housing and commercial development, but also for recreation and nature conservation. However, there are several problems connected to the redevelopment of brownfield, which may prevent the successful establishment of newly planted trees (Dickinson et al. 2005). In fact, because of the lack of topsoil, plant growth will rely on imported topsoil from other sites or on topsoil-forming amendments such as composted materials.

Organic compost materials generally have long-term beneficial effects on soil physical properties, although in the short term, these benefits are less evident (Watson 2002; Ferrini et al. 2005). Some research projects have shown that organic amendments have a potential role in ensuring quality restoration works (Hornick and Parr 1987; WRAP 2006) and their application is beneficial and relatively inexpensive (Vetterlein and Hüttl 1999). This works well with the European Union countries where the target is to decrease the quantity of organic waste going to landfill sites by $20 \%$ by 2010 and by 50\% by 2050 (Council Directive 1999/31/EC). The follow up of this directive could result in a large increase in composted organic wastes (Crowe et al. 2002).

Besides soil quality, other important components of planting sites are the open soil surface and the surface treatment over the rooting zone (Coder 1996; Trowbridge and Bassuk 2004).

In many urban sites, the soil surface is covered after planting; typical coverings of paving stones, asphalt, and concrete are impermeable to water and oxygen required by both the tree roots and the soil for proper functioning (Bradshaw et al. 1995). Metal grids or grates used in conjunction with concrete allow water and oxygen exchange only if the soil is not compacted and these grid or grates are also expensive.

Planting the area around the trees with small shrubby cover seems to have a very beneficial effect on soil humus and microorganisms (Bernatzky 1978). Benefits are probably the result of the fact that with groundcover, the risk of being walked on is much reduced.

The aims of this study were to evaluate the effects of backfill amendments, the size of the open soil area, and of the surface treatment on posttransplant growth and physiological characteristics of Acer platanoides L. trees planted in a postindustrial area after regeneration for commercial and housing uses.

\section{MATERIALS AND METHODS}

Twenty-four uniform, 5-year-old, 4 to $4.5 \mathrm{~m}$ (13.2 to $14.85 \mathrm{ft}$ ) tall, 14 to $16 \mathrm{~cm}$ (5.6 to 6.4 in) in circumference (measured at $1.3 \mathrm{~m}$ [4.29 ft] height), balled and burlapped Norway maple (Acer platanoides L.) 'Deborah' trees were planted before budbreak in an area in the city of Milan, Italy, which until the early 1990s was occupied by a truck factory. The existing brownfield soil was removed and replaced with a 120 to 150 $\mathrm{cm}$ (48 to $60 \mathrm{in}$ ) layer of clay-loam soil having an organic matter content of $2.8 \%$ (indicated as topsoil). Planting holes were three times the width and one and a half times the depth 
of the root ball (size of the root ball was 50 to $55 \mathrm{~cm} \mathrm{[20} \mathrm{to}$ 22 in] in diameter).

Trees were backfilled with: 1) topsoil with $25 \%$ composted material (volume/volume); 2) topsoil with $50 \%$ composted material; 3) topsoil with $75 \%$ composted material; or 4) topsoil only. Composted material was obtained from yard waste through aerobic biostabilization; compost was aerobic biostabilized with characteristics meeting the Italian standards (Table 1).

After planting, the soil surface was covered with: 1) an "opus incertum" pavement (this technique uses irregularly shaped, small, smoothed slabs of stone randomly fitted together with sealed joints $)$ and a metal grate $(1 \times 1 \mathrm{~m}[3.3 \times 3.3$ $\mathrm{ft}])$; 2) left free of pavement for an area of $2.5 \times 2.5 \mathrm{~m}(8.25$ $\times 8.25 \mathrm{ft})$ around the trunk $\left(6.25 \mathrm{~m}^{2}\left[67.5 \mathrm{ft}^{2}\right]\right)$, mulched with pine bark, and then planted with Viburnum davidii Franch.

Trees were planted in a completely randomized block design and regularly irrigated during spring and summer of each year. After the first year, some plants, regardless of the treatment, showed some dieback and were dropped from the measurements to obtain reliable data, measurements were performed on three single-plant replicates of four backfilling materials and six single replicates of planting area dimension. A CIRAS-1 portable infrared gas analyzer (PP Systems, Hertfordshire, UK) was used to determine instantaneous net photosynthesis $(\mathrm{Pn})$, transpiration rate $(\mathrm{E})$, and water use efficiency (WUE, calculated by dividing Pn by E) three times in the first and second year and five times in the third year (from mid-June through mid-August). Measurements of leaf gas exchange were started in mid-June. The readings were taken between 8:00 A.M. and 4:00 P.M. during sunny days (photosynthetically active radiation greater than $1000 \mu \mathrm{mol} / \mathrm{m}^{-2} /$ $\mathrm{s}^{-1}$ ) on ten fully expanded leaves from the outer part of the crown and at different heights per plant per treatment and repeated three times each day of measurements. Chlorophyll

Table 1. Average composition (percent on dry matter) of the mixed compost added to the planting pit.

\begin{tabular}{lcl}
\hline & $\begin{array}{l}\text { Value in } \\
\text { organic } \\
\text { compost } \\
\text { used }\end{array}$ & $\begin{array}{l}\text { Limit values } \\
\text { (according to } \\
\text { Italian Legislation) }\end{array}$ \\
Parameter & $13.9 \%$ & Maximum 50 \\
Humidity & 6.3 & $6.0-8.5$ \\
$\mathrm{pH}$ & $1.95 \%$ & - \\
Total nitrogen & $26.1 \%$ & Maximum 25 \\
Organic carbon & $45 \%$ & - \\
Organic matter & 13.4 & Maximum 25 \\
C/N ratio & $0.37 \%$ & - \\
Total phosphorus $\mathrm{P}_{2} \mathrm{O}_{5}$ & $1.00 \%$ & - \\
Potassium exchangeable $\mathrm{K}_{2} \mathrm{O}$ & & \\
Plastic materials (less than & $0.3 \%$ & Maximum 0.45 \\
$\quad 3.3$ mm [0.13 in]) & $0.7 \%$ & Maximum 0.9 \\
Total of inert material & & \\
\hline
\end{tabular}

content was determined in July and September on the same leaves with a portable chlorophyll meter (SPAD-502; Minolta Corp., Ramsey, NJ, U.S.). Previous calibration curves were established for the species by measuring absorbance at 664 , 647, and $625 \mathrm{~nm}$ with an Hitachi U-2000 spectrophotometer (Hitachi Ltd., Tokyo, Japan) after extraction with dimethylformamide (Moran 1982). Triplicate readings were taken around the midpoint near the midrib of each leaf sample and the values averaged.

Dry weight was determined on ten leaves per plant per treatment. The leaves were chosen from the outer part of the crown at different heights with similar conditions of shape and weight. Leaves were dried at $80^{\circ} \mathrm{C}\left(176^{\circ} \mathrm{F}\right)$ until constant weight.

In the second and third years of the experiment, leaves chosen from the same part of the tree were analyzed for mineral elements content by a specialized laboratory (MACMinoprio Analisi e Certificazioni).

Effects of compost addition and of mulch and paving surface and significant interactions between compost addition and of mulch and paving surface were determined by oneand two-way analyses of variance. Differences between treatment means were separated by the protected least significance difference at the $95 \%$ confidence level $(P \leq 0.05)$.

\section{RESULTS AND DISCUSSION}

\section{First Year}

The results from the first year indicate that the modification of the planting pit had no influence on leaf dry weight and leaf gas exchange. Only the transpiration rate was higher in the trees backfilled with topsoil $+75 \%$ compost and in the control ones. No significant differences were found regarding leaf chlorophyll content either (Table 2).

No statistical differences emerged regarding the size of the open soil surface with the exception of the WUE, which was higher in the trees that had mulch and groundcover planting.

The interactions between the two factors showed statistical significance, although not univocal; this is most likely the effect of transplant shock.

\section{Second Year}

In the second year after transplanting, leaf dry weight and leaf gas exchanges were not affected by soil amendments. Chlorophyll content was lower in the trees amended with $25 \%$ of composted material (Table 3).

The surface treatment had significant effects on all of the parameters measured. Trees growing with the pavement and grate had a lower leaf dry weight, reduced leaf gas exchange, and lower leaf chlorophyll content. These findings are similar to those of Celestian and Martin (2005) who compared four different ornamental species in two parking lot locations in United States, finding, in general, a higher leaf gas exchange and leaf chlorophyll content in the trees with the larger landscape area. 
Table 2. Year 1-Effect of backfill amending and of size of the paved surface on leaf dry weight (g), net photosynthesis ( $\mathrm{Pn}\left(\mu \mathrm{mol} / \mathrm{m}^{-2} / \mathrm{s}^{-1}\right.$ di $\left.\mathrm{CO}_{2}\right)$ ), transpiration rate $\left(\mathrm{E}\left(\mathrm{mmol} / \mathrm{m}^{-2} / \mathrm{s}^{-1}\right.\right.$ di $\left.\mathrm{H}_{2} \mathrm{O}\right)$ ), on water use efficiency (WUE (Pn/transpiration rate)), and on chlorophyll content $\left(\mathrm{mg} / \mathrm{cm}^{-2}\right.$ ) of Acer platanoides L. trees (first year). ${ }^{2}$

\begin{tabular}{lccccc}
\hline & Leaf dry weight & Pn & E & WUE & Chlorophyll \\
\hline Substrate & & & & & \\
$\quad$ Topsoil + compost $25 \%$ & $10.46 \mathrm{a}$ & $6.29 \mathrm{a}$ & $1.25 \mathrm{~b}$ & $5.77 \mathrm{a}$ & $16.78 \mathrm{a}$ \\
$\quad$ Topsoil + compost $50 \%$ & $9.25 \mathrm{a}$ & $5.53 \mathrm{a}$ & $1.09 \mathrm{~b}$ & $5.92 \mathrm{a}$ & $15.23 \mathrm{a}$ \\
$\quad$ Topsoil + compost $75 \%$ & $10.63 \mathrm{a}$ & $5.94 \mathrm{a}$ & $1.32 \mathrm{a}$ & $5.31 \mathrm{a}$ & $16.44 \mathrm{a}$ \\
$\quad$ Topsoil (control) & $8.7 \mathrm{a}$ & $6.43 \mathrm{a}$ & $1.49 \mathrm{a}$ & $5.21 \mathrm{a}$ & $16.78 \mathrm{a}$ \\
$P$ & 0.642 & 0.166 & 0.001 & 0.454 & 0.624 \\
Size of nonpaved surface & $10.23 \mathrm{a}$ & $5.84 \mathrm{a}$ & $1.37 \mathrm{a}$ & $4.99 \mathrm{~b}$ & $16.73 \mathrm{a}$ \\
$\quad 1 \mathrm{~m}^{2}\left(10.8 \mathrm{ft}^{2}\right)+$ metal grate & $9.20 \mathrm{a}$ & $6.37 \mathrm{a}$ & $1.29 \mathrm{a}$ & $5.92 \mathrm{a}$ & $16.10 \mathrm{a}$ \\
$6.25 \mathrm{~m}^{2}\left(67.5 \mathrm{ft}^{2}\right)+$ pine bark and groundcover & 0.422 & 0.166 & 0.256 & 0.009 & 0.440 \\
$P$ & & & & & \\
Interactions substrate $\times$ size & 0.793 & 0.000 & 0.003 & 0.005 & 0.000 \\
$P$ & & &
\end{tabular}

${ }^{\mathrm{z}}$ Data on leaf gas exchange are the average of three sampling dates, chlorophyll of two sampling dates. Values differ significantly when followed by different letters at $P \leq 0.05$ (least significant difference test).

Significant interactions were found between the two factors (substrate $\times$ size of paved surface). In general, compost addition did not show any positive effect on the trees with mulch treatment.

\section{Third Year}

Three years after transplanting, plants grown in amended soil had lower photosynthesis and transpiration rate throughout the growing season compared with the controls. Leaf dry weight and WUE were not affected, whereas chlorophyll content was lower in the trees that had $25 \%$ compost addition to the planting pit (Table 4).

Trees with the mulch treatment performed significantly better for all the parameters measured. There are probably several reasons why trees grown under pavement or grates had lower leaf gas exchange activity. Research has shown that woody plant gas exchange is largely controlled by the response of the trees to the environment. Therefore, leaves of trees planted with a paved surface can have greater leaf temperature and lower leaf gas exchange than trees under planted with a vegetative surface which indirectly effects plant physiology (Montague and Kjelgren 2004).

The interactions between the two factors of variability (substrate and size of paved surface) were significant for all the parameters expect leaf dry weight. In general, as observed in the previous year, trees grown under paved soil surface showed higher values for most of the parameters proportionally to the compost amount added to the planting pit, suggesting that compost addition can be a valuable tool to mitigate the negative effects of covering the planting area. On

Table 3. Year 2-Effect of backfill amending and of size of paved surface on leaf dry weight (g), net photosynthesis $\left(\mathrm{Pn}\left(\mu \mathrm{mol} / \mathrm{m}^{-2} / \mathrm{s}^{-1}\right.\right.$ di $\left.\mathrm{CO}_{2}\right)$ ), transpiration rate $\left(\mathrm{E}\left(\mathrm{mmol} / \mathrm{m}^{-2} / \mathrm{s}^{-1}\right.\right.$ di $\left.\mathrm{H}_{2} \mathrm{O}\right)$ ), on water use efficiency (WUE (Pn/transpiration rate)), and on chlorophyll content $\left(\mathrm{mg} / \mathrm{cm}^{-2}\right.$ ) of Acer platanoides $\mathrm{L}$. trees (first year). ${ }^{2}$

\begin{tabular}{|c|c|c|c|c|c|}
\hline & Leaf dry weight & $\mathrm{Pn}$ & $\mathrm{E}$ & WUE & Chlorophyll \\
\hline \multicolumn{6}{|l|}{ Substrate } \\
\hline Topsoil + compost $25 \%$ & $17.23 \mathrm{a}$ & $4.333 \mathrm{a}$ & $1.146 \mathrm{a}$ & $3.74 \mathrm{a}$ & $9.61 \mathrm{~b}$ \\
\hline Topsoil + compost $50 \%$ & $17.94 \mathrm{a}$ & $3.930 \mathrm{a}$ & $1.090 \mathrm{a}$ & $3.48 \mathrm{a}$ & $11.59 \mathrm{a}$ \\
\hline Topsoil + compost $75 \%$ & $16.46 \mathrm{a}$ & $2.975 \mathrm{a}$ & $1.185 \mathrm{a}$ & $2.66 \mathrm{a}$ & $10.91 \mathrm{a}$ \\
\hline Topsoil (control) & $17.48 \mathrm{a}$ & $4.806 \mathrm{a}$ & $1.401 \mathrm{a}$ & $3.53 \mathrm{a}$ & $11.48 \mathrm{a}$ \\
\hline$P$ & 0.951 & $0.191 \mathrm{a}$ & $0.131 \mathrm{a}$ & 0.410 & 0.007 \\
\hline $6.25 \mathrm{~m}^{2}\left(67.5 \mathrm{ft}^{2}\right)+$ pine bark and groundcover & $18.667 \mathrm{a}$ & $5.437 \mathrm{a}$ & $1.36 \mathrm{a}$ & $4.14 \mathrm{a}$ & $12.72 \mathrm{a}$ \\
\hline$P$ & 0.048 & 0.000 & 0.006 & 0.001 & 0.000 \\
\hline \multicolumn{6}{|l|}{ Interactions substrate $\times$ size } \\
\hline$P$ & 0.805 & 0.000 & 0.084 & 0.000 & 0.000 \\
\hline
\end{tabular}

${ }^{\mathrm{z}}$ Data on leaf gas exchange are the average of three sampling dates, chlorophyll of two sampling dates. Values differ significantly when followed by different letters at $P \leq 0.05$ (least significant difference test). 
Table 4. Year 3-Effect of backfill amending and of size of paved surface on leaf dry weight (g), net photosynthesis $\left(\mathrm{Pn}\left(\mu \mathrm{mol} / \mathrm{m}^{-2} / \mathrm{s}^{-1}\right.\right.$ di $\left.\mathrm{CO}_{2}\right)$ ), transpiration rate $\left(\mathrm{E}\left(\mathrm{mmol} / \mathrm{m}^{-2} / \mathrm{s}^{-1}\right.\right.$ di $\left.\mathrm{H}_{2} \mathrm{O}\right)$ ), on water use efficiency (WUE (Pn/transpiration rate)), and on chlorophyll content $\left(\mathrm{mg} / \mathrm{cm}^{-2}\right.$ ) of Acer platanoides $\mathrm{L}$. trees (first year). ${ }^{2}$

\begin{tabular}{lllllr}
\hline & Leaf dry weight & Pn & E & WUE & Chlorophyll \\
\hline Substrate & & & & & \\
Topsoil + compost 25\% & $9.85 \mathrm{a}$ & $5.27 \mathrm{~b}$ & $1.88 \mathrm{~b}$ & $2.99 \mathrm{a}$ & $10.81 \mathrm{~b}$ \\
Topsoil + compost 50\% & $8.20 \mathrm{a}$ & $5.25 \mathrm{~b}$ & $1.84 \mathrm{~b}$ & $3.14 \mathrm{a}$ & $12.59 \mathrm{a}$ \\
Topsoil + compost $75 \%$ & $8.40 \mathrm{a}$ & $4.74 \mathrm{~b}$ & $1.97 \mathrm{ab}$ & $2.59 \mathrm{a}$ & $12.32 \mathrm{a}$ \\
Topsoil (control) & $7.90 \mathrm{a}$ & $6.15 \mathrm{a}$ & $2.23 \mathrm{a}$ & $2.98 \mathrm{a}$ & $12.68 \mathrm{a}$ \\
$P$ & 0.860 & 0.004 & 0.010 & 0.222 & 0.000 \\
Size of nonpaved surface & & & & \\
$1 \mathrm{~m}^{2}\left(10.8 \mathrm{ft}^{2}\right)+$ metal grate & $6.50 \mathrm{a}$ & $3.70 \mathrm{~b}$ & $1.41 \mathrm{~b}$ & $2.74 \mathrm{~b}$ & $9.59 \mathrm{~b}$ \\
$6.25 \mathrm{~m}^{2}\left(67.5 \mathrm{ft}^{2}\right)+$ pine bark and groundcover & $9.433 \mathrm{a}$ & $6.74 \mathrm{a}$ & $2.43 \mathrm{a}$ & $3.09 \mathrm{a}$ & $13.89 \mathrm{a}$ \\
$P$ & 0.057 & 0.000 & 0.000 & 0.039 & 0.000 \\
Interactions substrate $\times$ size & & & & & 0.000 \\
$P$ & 0.606 & 0.000 & 0.000 & 0.014 & 0.000 \\
\hline
\end{tabular}

${ }^{\mathrm{z}}$ Data on leaf gas exchange are the average of three sampling dates, chlorophyll of two sampling dates. Values differ significantly when followed by different letters at $P \leq 0.05$ (least significant difference test).

the other hand, as observed in the previous year, trees grown in the larger mulched area had lower values for most of the parameters proportional to the compost amount added to the planting pit, supporting the hypothesis that no real benefit can be derived from the use of soil amendments when a good clay loam soil is present and when the space around the tree is not limiting (Shulte and Whitcomb 1975).

\section{Leaf Mineral Content}

During the second and third year after transplanting, there was no apparent effect from adding compost to the backfill soil on leaf mineral content (Table 5). All foliar nitrogen levels were low and did not increase consistently after compost addition. Similarly, no significant differences were detected for the other elements.

With surface treatments in both years, a higher content of nitrogen, phosphorus, and calcium was detected for the trees grown with the mulched surface. Potassium and magnesium were not affected (Table 5). Similar to what was found for the other parameters, significant interactions emerged between the two factors (size of paved area $\times$ backfill composition).

It is probable that the higher soil/atmosphere gas exchange in the mulched treatment has enhanced the availability and uptake of some mineral elements. In fact, pavement decreases gas exchange between atmosphere and soil and, therefore, the oxygen supply to the roots (Koolen and Rossignol 1998). A reduced root growth and activity negatively influences nutrient uptake and physiology; our data confirm this hypothesis.

\section{CONCLUSIONS}

The results obtained show that the size and type of the unpaved area determines tree health. A larger mulched area with groundcover planting was superior to a smaller paved area.

Table 5. Effect of planting pit modifications and of open soil surface on leaf mineral content (percent on dry matter). ${ }^{z}$

\begin{tabular}{|c|c|c|c|c|c|}
\hline & Nitrogen & Phosphorus & Potassium & Calcium & Magnesium \\
\hline \multicolumn{6}{|l|}{ Substrate } \\
\hline Topsoil + compost $25 \%$ & $1.48 \mathrm{a}$ & $0.18 \mathrm{a}$ & $0.91 \mathrm{a}$ & $1.354 \mathrm{a}$ & $0.15 \mathrm{a}$ \\
\hline Topsoil + compost $50 \%$ & $1.65 \mathrm{a}$ & $0.19 \mathrm{a}$ & $0.90 \mathrm{a}$ & $1.67 \mathrm{a}$ & $0.15 \mathrm{a}$ \\
\hline Topsoil + compost $75 \%$ & $1.35 \mathrm{a}$ & $0.13 \mathrm{a}$ & $0.42 \mathrm{a}$ & $1.80 \mathrm{a}$ & $0.13 \mathrm{a}$ \\
\hline Topsoil (control) & $1.65 \mathrm{a}$ & $0.16 \mathrm{a}$ & $0.44 \mathrm{a}$ & $2.20 \mathrm{a}$ & $0.19 \mathrm{a}$ \\
\hline$P$ & 0.488 & 0.693 & 0.239 & 0.433 & 0.500 \\
\hline $6.25 \mathrm{~m}^{2}\left(67.5 \mathrm{ft}^{2}\right)+$ pine bark and groundcover & $1.85 \mathrm{a}$ & $0.19 \mathrm{a}$ & $0.71 \mathrm{a}$ & $2.20 \mathrm{a}$ & $0.18 \mathrm{a}$ \\
\hline$P$ & 0.027 & 0.019 & 0.290 & 0.014 & 0.056 \\
\hline \multicolumn{6}{|l|}{ Interactions substrate $\times$ size } \\
\hline$P$ & 0.702 & 0.000 & 0.002 & 0.008 & 0.000 \\
\hline
\end{tabular}

${ }^{2}$ Data represent the average of 2 years' analyses. Values differ significantly when followed by different letters at $P \leq 0.05$ (least significant difference test). 
No tree growth benefits were observed by adding composted materials to the planting pit at the time of transplanting Norway maple in an area previously covered with good topsoil. This confirms findings by other authors who did not find appreciable effects after compost addition to the planting pit (Gilman 2004). The effects of compost addition can be expected only after some years as a result of soil microbial activity and organic matter mineralization. This study, therefore, suggests that topsoil, even a clay one, is a satisfactory substrate for Acer platanoides and that the amount of compost to be added should be determined according to native soil characteristics.

Acknowledgments. Support for this project came in part from the Regione Toscana (Italy) inside the research project "Research on multipurpose green areas" (RISVEM). We thank Dr. Giovanni Sala and Studio Land SRL for their support to the research.

\section{LITERATURE CITED}

Bernatsky, A. 1978. Tree Ecology and Preservation. Elsevier, Amsterdam. 357 pp.

Bradshaw, A., B. Hunt, and T. Walmsley. 1995. Trees in the Urban Landscape: Principles and Practice. E \& FN Spon, London. 288 pp.

Celestian, S.B., and C.A. Martin. 2005. Effects of parking lot location on size and physiology of four southwestern U.S. landscape trees. Journal of Arboriculture 31:191-197.

Coder, K. 1996. Tree planting area size: Futuring resource availability and identifying constraints. University of Georgia Cooperative Extension Service Forest Resources Unit FOR96-38.

Crowe, M., K. Nolan, C. Collins, G. Carty, B. Donlon, and M. Kristoffersen. 2002. Biodegradable municipal waste management in Europe. European Environment Agency, Kongens Nytorv 6, DK-1050 Copenhagen K. www.eea. eu.int (accessed 6/2006).

Dickinson, N.M., W. Hartley, L.A. Uffindell, A.N. Plumb, H. Rowlinson, and P. Putwain. 2005. Robust biological descriptors of soil health for use in reclamation of brownfield land. Land Contamination \& Reclamation 13:1-10.

Ferrini, F., A. Giuntoli, F.P. Nicese, S. Pellegrini, and N. Vignozzi. 2005. Effect of fertilization and backfill amendments on soil characteristics, growth and leaf gas exchanges of English oak (Quercus robur L.). Journal of Arboriculture 32:93-99.

Gilman, E.F. 2004. Effects of amendments, soil additives, and irrigation on tree survival and growth. Journal of Arboriculture 30:301-305.

Hornick, S.B., and J.F. Parr. 1987. Restoring the productivity of marginal soils with organic amendments. American Journal of Alternative Agriculture 2:64-68.
Koolen, A.J., and J.P. Rossignol. 1998. Introduction to symposium 19: Construction and use of artificial soils. Soil and Tillage Research 47:151-155.

Montague, T., and R. Kjelgren. 2004. Energy balance of six common landscape surfaces and the influence of surface properties on gas exchange of four containerized tree species. Scientia Horticulturae 100:229-249.

Moran, R. 1982. Formulae for determination of chlorophyllous pigments extracted with $\mathrm{N}, \mathrm{N}$-dimethylformamide. Plant Physiology 69:1376-1381.

Shulte, J.R., and C.E. Whitcomb. 1975. Effects of soil amendments and fertilizer levels on the establishment of silver maple. Journal of Arboriculture 1:192-195.

Trowbridge, P.J., and N.L. Bassuk. 2004. Trees in the Urban Landscape: Site Assessment, Design and Installation. John Wiley \& Sons, Inc., Hoboken, NJ. 207 pp.

Vetterlein, D., and R.F. Hüttl. 1999. Can applied organic matter fulfill similar function as soil organic matter? Risk-benefit analysis for organic matter application as a potential strategy for rehabilitation of disturbed ecosystems. Plant and Soil 213:1-10.

Watson, G.W. 2002. Soil replacement: Long-term results. Journal of Arboriculture 28:229-230.

WRAP. 2006. Uses of compost in regeneration and remediation of brownfield sites in the UK. The Waste \& Resources Action Programme The Old Academy, Banbury, Oxon. www.wrap.org.uk (accessed 6/2006).

Francesco Ferrini (corresponding author)

Full Professor

Dipartimento di Ortoflorofrutticoltura

University of Florence

Viale delle Idee

30-50019, Sesto Fiorentino (Florence), Italy

francesco.ferrini@unifi.it

Manuela Baietto

PhD Student

Dipartimento di Produzione Vegetale

University of Milan

Via Celoria, 2-20133, Milano, Italy

Résumé. Dans ce projet nous avons comparé l'effet d'un remblai amendé avec un compost ainsi que la superficie de la surface exposée sur des érables de Norvège (Acer platanoides L.) plantés dans un terreau de plantation de qualité élevée sur un terrain en terre brune où il y avait autrefois une manufacture de camions. Après trois ans, les arbres avec un milieu plus vaste et une superficie en paillis plus grande avaient des échanges foliaires gazeux plus importants ainsi qu'un contenu minéral et en chlorophylle foliaire plus grands que ceux poussant en milieu pavé. Les effets des différentes quantités de compost dans le terreau de plantation ont été plus difficiles à évaluer à l'intérieur du cadre de cette étude. Même si ces effets 
pourraient devenir significatifs à long terme, il est difficile de prescrire un ajout de compost comme bonne technique pour améliorer la croissance de la plante et sa physiologie lorsque le sol original a été entièrement remplacé par un bon terreau de surface.

Zusammenfassung. In dieser Arbeit vergleichen wir die Effekte von mit Kompost angereichertem Füllboden und der Größe von der exponierten Oberfläche von Acer platanoides-Bäumen, die in Qualitätsfüllboden auf einem Industriestandort, der vorher von einer LKW-Firma genutzt wurde, gepflanzt wurden. Nach drei Jahren hatten Bäume mit größeren und gemulchten Pflanzflächen eine höheren Gasaustausch, Blattchorophyll und Mineralstoffgehalt als die Bäume, die unter Pflasterflächen wuchsen. Die Effekte der unterschiedlichen Quantitäten von Kompost in dem Füllboden waren innerhalb der Rahmenbedingungen dieser Studie schwieriger zu untersuchen. Obwohl diese Effekte auf lange Sicht bedeutsam werden können, ist es schwierig zu sagen, die Zugabe von Kompost als eine nützliche Technik zur Verbesserung von Pflanzenwachstum und Physiologie zu beschreiben, wenn natürliche Böden komplett durch einen guten Oberboden ersetzt wurden.

Resumen. En este trabajo se comparó el efecto de las compostas mejoradas para el relleno y el tamaño del área superficial expuesta, en árboles de maple Norway (Acer platanoides L.) plantados en un área previamente ocupada por una fábrica. Después de tres años, los árboles con áreas de plantación más grandes tuvieron más altos intercambio de gases, contenido de minerales y clorofila foliar, que aquellos que crecieron bajo pavimento. Los efectos de las diferentes cantidades de composta en el relleno fueron difíciles de evaluar dentro del esquema de este estudio. A pesar de que estos efectos pueden ser significativos a largo plazo, es difícil prescribir la adición de composta como una técnica útil para mejorar el crecimiento y la fisiología de las plantas donde el suelo nativo ha sido remplazado completamente por una buena capa superior. 